\title{
Coccinellidae captured in blacklight traps: Seasonal and diel pattern of the dominant species Harmonia axyridis (Coleoptera: Coccinellidae)
}

\author{
Christine A. NALEPA \\ Beneficial Insects Laboratory, Plant Industry Division, North Carolina Department of Agriculture \& Consumer Services, \\ 1060 Mail Service Center, Raleigh, NC 27699-1060, USA; e-mail: christine.nalepa@ncagr.gov
}

\begin{abstract}
Key words. Coleoptera, Coccinellidae, Harmonia axyridis, Coleomegilla maculata, Hippodamia convergens, Coccinella septempunctata, blacklight trap, ultraviolet, migration, phototaxis, flight-oogenesis, nocturnal
\end{abstract}

\begin{abstract}
Two blacklight traps were operated in a non-agricultural setting in Cary, North Carolina, USA, from spring through fall in 2004 and 2005 and all Coccinellidae collected and identified. More than 1300 lady beetles were collected in each of the two years, with Harmonia axyridis dominant (>98\%) and collected consistently over the course of the trapping period. Although other coccinellid species were observed in the vicinity of the traps during photophase, their appearance in blacklight traps was negligible. Harmonia axyridis exhibited a distinct diel periodicity in appearance at the traps, beginning approximately an hour after sunset and ending about midnight. Sunrise and sunset collections from flight interference and sticky traps in a local alfalfa field suggest that $H$. axyridis may be more flight active during the scotophase than Coleomegilla maculata, Hippodamia convergens, and Coccinella septempunctata. This study supports the suggestion that blacklight traps give a biased depiction of coccinellid species composition in a given area, and indicates that seasonal and circadian thresholds for flight activity, phototaxis, or both in $H$. axyridis may diverge from those in most other Coccinellidae.
\end{abstract}

\section{INTRODUCTION}

Ladybird beetles (Coccinellidae) are primarily visual predators active during daylight hours (Hodek \& Honěk, 1996). There are nonetheless numerous records indicating that they are attracted to light traps, particularly blacklight (ultraviolet $=$ UV) traps. Nabli et al. (1999), for example, documented the attraction of Coccinellidae to blacklight traps, although individual species were not identified, and Honěk et al. (2005) reported the appearance of Adalia spp. at mercury vapour lamps, which have a UV component. Blacklight traps seem particularly effective in capturing Harmonia axyridis Pallas, an effective aphid predator, but a species of increasing concern as it continues to invade new countries, displace native coccinellids, decrease the market value of ripe grapes and other fruit, and act as both a nuisance and allergen in buildings during its overwintering period (Kenis et al., 2008; Soares et al., 2008). The first documentation of $H$. axyridis in a new geographic area is often due to its capture in blacklight traps (Chapin \& Brou, 1991; Stanković et al., 2011). These traps also have been used to determine peak activity of $H$. axyridis in agricultural landscapes (Galvan et al., 2009) and to catch adults in dark, confined spaces inside buildings during the winter aggregation period (e.g., Waldvogel et al., 2003; Kenis et al., 2008). There are indications that $H$. axyridis is strongly and consistently attracted to blacklight traps, while appearance of other coccinellid species is more sporadic (Hesler et al., 2004). The present study was initiated to identify all coccinellid fauna attracted to blacklight traps in a nonagricultural area in central North Carolina, USA. Following initial results, the aim of the study shifted to exploring aspects of the attraction of $H$. axyridis to blacklight traps in more detail.

\section{MATERIAL AND METHODS}

\section{Light trap samples}

Two Gempler's (Madison, Belleville, WI) blacklight traps fitted with Sylvania F15W/ BL350 bulbs (55 w, 315-400 nm, peak $352 \mathrm{~nm}$ ) and with Hercon Vaportape II insecticidal strips (Aberdeen Road Company, Emigsville, PA) placed in the collection tank were set up on the grounds of the North Carolina Department of Agriculture Beneficial Insects Laboratory in Cary, in the piedmont of North Carolina $\left(35.79^{\circ} \mathrm{N}, 78.73^{\circ} \mathrm{W}\right.$, $146 \mathrm{~m}$ elevation), USA. The laboratory is situated on a former research farm now encroached by recreational fields and light industry, and with some residential use. Trap 1 was situated $8 \mathrm{~m}$ northwest of the laboratory, at the edge of approximately 1 ha of lawn interspersed with stands of diverse ornamentals. Trap 2 was located south of the building in similar habitat, approx. 86 $\mathrm{m}$ from Trap 1. Adjacent unmanaged plots were dominated by wild blackberry (Rubus sp.), dog fennel [Eupatorium capillifolium (Lam.)], and Baccharis halimifolia L. Both traps were within sight of mixed pine and hardwood stands.

In both 2004 and 2005, the traps were set up at the beginning of the first week of April and run continuously through September (2004) or October (2005). Both traps were checked and emptied of coccinellids in the early morning every 1-3 days, and the collections from the two traps combined for analysis. Two additional years of supplemental data were obtained by running a single trap (Trap 1) from 28 March to 24 July 2007 and 28 April to 7 July 2008 .

\section{Diel pattern of attraction to blacklight traps}

To determine patterns of daily flight, blacklight traps (as above) were erected in the same two locations on 15 August 2006, and studies conducted on 23-25 August and 15-17 September. Following preliminary, night-long observations, traps 

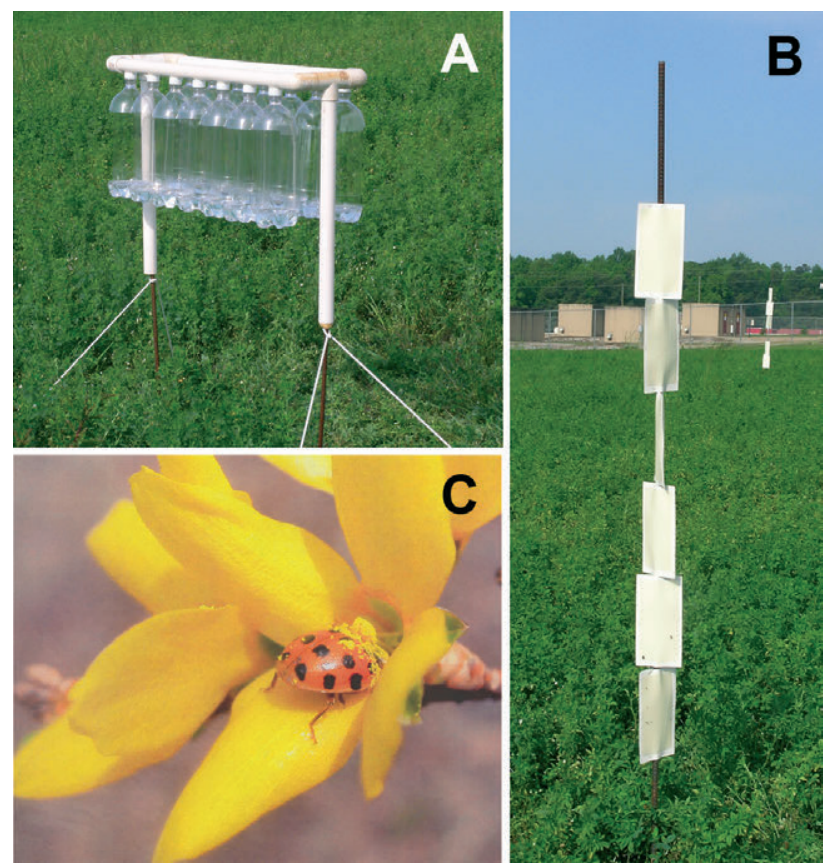

Fig. 1. A - Flight interception trap made from soda bottles; B - Sticky trap tower; $\mathrm{C}$ - Harmonia axyridis feeding on pollen prior to first appearance at blacklight traps.

were checked on these six days hourly from 17:00 until sunset, and at half-hour intervals from sunset until midnight. Hourly checks resumed at 05:00 the following morning and were discontinued at 08:00. Beetles trapped between midnight and 05:00 were evident in the first morning collection. At each check all live coccinellids on traps and dead coccinellids in traps were removed and counted. Sunrise occurred at 06:39-06:40 during the August test period and at 07:19-07:22 during the September test period. Sunset occurred at 19:54-19:51 during the August test period, and 19:22-19:19 during the September test period. The moon was in its last quarter on August 23 and full on September 15 .

\section{Day vs. night activity}

In spring of 2008 a study was conducted to begin identifying behaviors that may have resulted in differential blacklight catch of coccinellid species. Day vs. night collections were carried out using both flight interception traps and sticky traps in an alfalfa field (Medicago sativa L.) on Lake Wheeler Research Station, North Carolina State University, Raleigh, North Carolina $\left(35^{\circ} 44^{\prime} 2.94^{\prime \prime} \mathrm{N}, 78^{\circ} 40^{\prime} 23.72^{\prime \prime} \mathrm{W}\right)$, located $9.3 \mathrm{~km}$ from the light traps. The goal was to compare coccinellid flight activity during the photophase and scotophase while minimizing the phototactic behavioral component inherent in blacklight traps.

The flight interception trap consisted of a double row of clear $1 \mathrm{~L}$ plastic soda bottles ( $\mathrm{n}=14$ bottles, 7 in each row). A $13 \times$ $17 \mathrm{~cm}$ window was removed on one side of each bottle. Bottle caps were glued to $3.5 \mathrm{~cm}$ diameter polyvinylchloride (pvc) pipes, and the bottles attached to the caps with the cut windows positioned toward the open field; $2-3 \mathrm{~cm}$ of soapy water was added to the bottom of each bottle. The base of each cut window was $\sim 40 \mathrm{~cm}$ above the canopy. Steel rods supported the pvc pipes, and were anchored in the alfalfa field using standard tent stakes (Fig. 1a). Four towers of sticky traps were situated $15 \mathrm{~m}$ from the interception trap on the principal compass points. A tower consisted of six pairs of sticky traps, with two traps stapled together at the edges, glue facing out, and slid onto a steel rod support. The traps were white, $10 \times 20 \mathrm{~cm}$ Trapper Ltd glue traps (Bell Laboratories, Inc., Madison WI). The bottom pair of traps was situated just above the alfalfa canopy $(30-40 \mathrm{~cm}$ high) and each successive pair above was rotated a quarter turn (Fig. 1b). The flight interception and sticky traps were set up in the center of the 1.2 ha field on the morning of 2 May 2008 and examined at sunset and sunrise for seven consecutive days. All coccinellids found were removed and identified at each visit.

Temperature data were obtained from the National Weather Service Climate Report for Raleigh-Durham International Airport, located approx. $10 \mathrm{~km}$ from the blacklight traps. Data on celestial events were taken from the Naval Oceanography Portal of the United States Naval Observatory (http://www.usno.navy. $\mathrm{mil} / \mathrm{USNO}$ )

\section{RESULTS}

\section{Blacklight traps}

A total of 1600 beetles were collected from the blacklight traps in 2004, and 1352 were collected in 2005. Harmonia axyridis overwhelmingly dominated the collection in both years, making up $98.4 \%$ of the catch in 2004 and $99 \%$ in 2005 (Table 1). Supplemental data collected in 2007 and 2008 corroborate these results. In 2007, 217 coccinellids were captured, with $98 \% H$. axyridis and $2 \%$ Coccinella septempunctata L. In 2008, 64 beetles were captured, with 94\% H. axyridis, 3\% C. septempunctata, and 3\% Myzia pullata (Say). Twenty M. pullata collected from the blacklight traps 29 March - 18 July 2004 were dissected; nineteen were females, and of these, one had well-developed ovarioles. These dissections were recent and opportunistic (i.e., hindsight), as the M. pullata specimens were the only ones retained from the study.

Between 29 September and 18 October 2005, adults of C. septempunctata, Hippodamia convergens Guer.,

TABLE 1. Two years of data on the number and species of Coccinellidae pooled from two blacklight traps in Cary, NC.

\begin{tabular}{|c|c|c|c|c|}
\hline \multirow{2}{*}{ Species } & \multicolumn{2}{|c|}{2004} & \multicolumn{2}{|c|}{2005} \\
\hline & No. & Dates & No. & Dates \\
\hline Harmonia axyridis Pallas & 1575 & See Fig. 2 & 1339 & See Fig. 2 \\
\hline Myzia pullata (Say) & 20 & 29 Mar - 18 July & 7 & 10 May - 7 June \\
\hline Coccinella septempunctata $\mathrm{L}$. & 2 & 6, 9 May & 4 & 9, 19 May; 17 Oct \\
\hline Cycloneda munda Say & 2 & 22, 28 May & 0 & \\
\hline Anatis quindecimpunctata (Oliver) & 0 & & 1 & 30 June \\
\hline Hippodamia convergens Guer. & 0 & & 1 & 2 Aug \\
\hline Psyllobora vigintimaculata (Say) & 1 & 15 July & 0 & \\
\hline
\end{tabular}




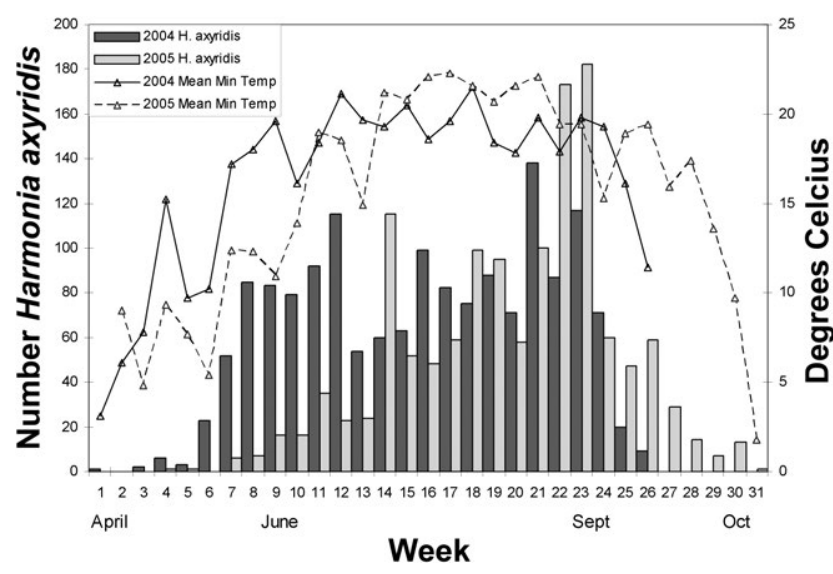

Fig. 2. Weekly totals of Harmonia axyridis in blacklight traps in relation to weekly mean minimum temperature in 2004 and 2005.

Cycloneda munda Say, and $H$. axyridis were all noted in an aphid-infested field of dog fennel immediately adjacent to the blacklight traps, but only H. axyridis was captured in the traps. In a 2005 study conducted simultaneously on a plot adjacent to the blacklight traps (40 m from Trap 1), coccinellids captured by pitcher plants (Sarracenia flava L.) were collected $(\mathrm{n}=57)$. Harmonia axyridis comprised $50 \%$ of the catch, while C. septempunctata was $26 \%, C$. munda was $9 \%, H$. convergens was $7 \%$, and Coleomegilla maculata De Geer was $7 \%$.

Harmonia axyridis leave winter hibernation sites by the second week of March in central North Carolina (unpubl. observ.), but few were collected in blacklight traps before mid to late April. On 29 March 2005, 122 adult H. axyridis were hand-collected as they fed on the pollen of Forsythia sp. (Fig. 1c) $6 \mathrm{~km}$ east of the light traps. The first appearance of an adult $H$. axyridis in a light trap that year was nearly a month later, during the last week of April.

Early season collections of $H$. axyridis were higher in 2004 than in 2005, correlating with the warm spring of 2004 (Fig. 2). Conversely, late season warm temperatures in 2005 were reflected in lingering autumnal blacklight catches of $H$. axyridis. In both years, sharply defined peaks of generational emergence of $H$. axyridis adults

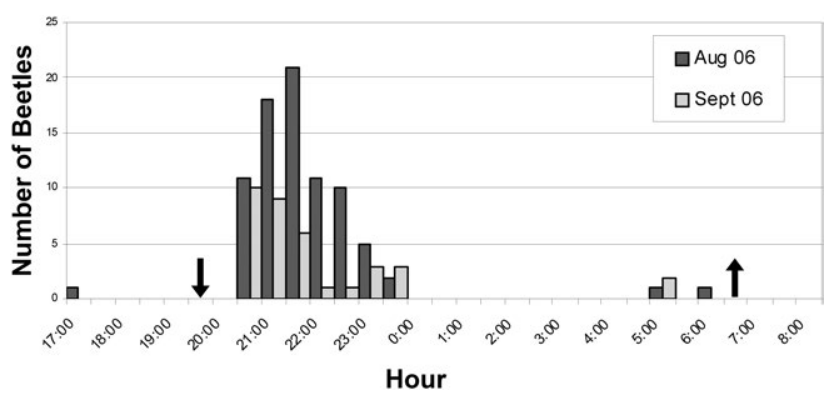

Fig. 3. Diel pattern of blacklight trap catches of Harmonia axyridis summed over three days in August (23-25) and three days in September (15-17) 2006. Arrow pointing down indicates sunset, arrow pointing up indicates sunrise. Beetles captured after midnight are evident in the 05:00 collection.

were not apparent, although there was a strong early autumn catch in 2005 .

\section{Flight pattern of Harmonia axyridis}

There is a distinct diel periodicity to the arrival of $H$. axyridis at blacklight traps (Fig. 3). Beetles were first trapped after astronomical twilight, approximately one $\mathrm{hr}$ after sunset. Despite a few stragglers, flight was essentially over at midnight, even if temperatures remained favorable for flight. On the night of 25-26 August, for example, 25 beetles were trapped before midnight, and one after midnight, despite a temperature of $22.2^{\circ} \mathrm{C}$ at 02:00.

\section{Day vs. night collection of coccinellids in alfalfa}

Four coccinellid species were present in the alfalfa field site during 2-9 May 2008: Cycloneda munda, Hippodamia convergens, Coccinella septempunctata, and Harmonia axyridis. A total of 231 beetles were collected during the sunset trap check, representing beetles active during the day (Table 2); 34 beetles were collected in the bottle traps and 197 beetles on the sticky traps. These were dominated by $C$. septempunctata $(48.1 \%)$, with $H$. axyridis making up $12.6 \%$ of the catch. Just 10 beetles were found in traps during the sunrise check; of these, two were C. munda, and eight were H. axyridis (80\%). Of the ten night-flying beetles, nine were captured on the sticky traps and one in the bottle trap. There is a signifi-

TABLE 2. Day vs. night collection of Coccinellidae using sticky traps and flight interception traps in an alfalfa field, Lake Wheeler Research Station, Raleigh, NC, May 2008. Cm - Cycloneda munda; Hc - Hippodamia convergens; Cs - Coccinella septempunctata; $\mathrm{Ha}$ - Harmonia axyridis; Min. Temp. - minimum temperature of previous night $\left({ }^{\circ} \mathrm{C}\right)$.

\begin{tabular}{|c|c|c|c|c|c|c|c|c|c|c|c|}
\hline \multirow{2}{*}{ Date } & \multicolumn{6}{|c|}{ Sunrise collection } & \multicolumn{5}{|c|}{ Sunset collection } \\
\hline & $\mathrm{Cm}$ & $\mathrm{Hc}$ & Cs & $\mathrm{Ha}$ & Total & Min. Temp. & $\mathrm{Cm}$ & $\mathrm{Hc}$ & Cs & $\mathrm{Ha}$ & Total \\
\hline 2 May & & & & & & & 0 & 27 & 19 & 3 & 49 \\
\hline 3 May & 0 & 0 & 0 & 0 & 0 & 15.6 & 0 & 15 & 15 & 2 & 32 \\
\hline 4 May & 0 & 0 & 0 & 1 & 1 & 16.1 & 0 & 11 & 23 & 3 & 37 \\
\hline 5 May & 0 & 0 & 0 & 6 & 6 & 14.4 & 0 & 3 & 8 & 10 & 21 \\
\hline 6 May & 0 & 0 & 0 & 1 & 1 & 12.2 & 0 & 10 & 18 & 10 & 38 \\
\hline 7 May & 0 & 0 & 0 & 0 & 0 & 11.1 & 0 & 17 & 18 & 0 & 35 \\
\hline 8 May & 1 & 0 & 0 & 0 & 1 & 18.3 & 0 & 8 & 10 & 1 & 19 \\
\hline 9 May & 1 & 0 & 0 & 0 & 1 & 20.0 & & & & & \\
\hline Total & 2 & 0 & 0 & 8 & 10 & & 0 & 91 & 111 & 29 & 231 \\
\hline
\end{tabular}


cant difference in the frequency at which $H$. axyridis was captured during the day vs. night relative to all other coccinellid species $(P<0.001$; Fisher's Exact Test).

\section{DISCUSSION}

The data indicate that $H$. axyridis were overrepresented in blacklight traps when compared to coccinellid species visually noted on plants in proximity to the traps, and to those captured in Sarracenia pitcher plants nearby. Collection of any species but $H$. axyridis was rare in both 2004 and 2005, despite other ladybird species present and presumably within the trap sphere of influence. The current study supports the suggestion that sampling with blacklight traps can bias documentation of the relative abundance of coccinellid species in a given area (Koch \& Hutchinson, 2003; Hesler et al., 2004).

The seasonal initiation of $H$. axyridis flight activity to the traps differed in the two years of the study, and was roughly correlated with spring temperatures (Fig. 2). Although adults had left winter aggregation sites and were active during the day in March 2005 (Fig. 1c), they were not captured in traps until approximately a month later. The large number of $H$. axyridis collected at the end of summer in 2005 was likely linked to lingering warm temperatures and the associated persistence of an aphid food source on dog fennel in a nearby field. It is unknown whether seasonal temperatures influenced flight activity, response to ultraviolet light, or both. Temperature is known to not only dramatically influence flight activity when adults are seeking winter shelter (Nalepa et al., 2005), but also the polarity of phototaxis during the aggregation period (Nalepa, 2007).

The diel pattern of $H$. axyridis attraction to blacklight traps in this location differs from that of a recent study conducted in crops in China. Ma \& Ma (2012) found pest Coleoptera in traps between 20:00 and 22:00, but the two Coccinellidae they monitored, $H$. axyridis and Propylea japonica, displayed no obvious activity peaks; similar numbers were trapped throughout the night. In the present study, $H$. axyridis began appearing at the traps about an hour after sunset, presumably when the contrast between the UV light source and its surroundings was high enough (Southwood, 1978; Gerson \& Kelsey, 1997). Cessation of $H$. axyridis appearance at traps after midnight in this study may be related to the seasonal timing of the study, late summer, or to the non-crop setting.

The accumulating evidence suggests that $H$. axyridis may have a relationship to blacklight traps that differs from that of most Coccinellidae. Koch \& Hutchinson (2003) attribute these differences to trap placement, aphid abundance, temperature, or relative abundance in the landscape. Biological interpretation of the data is difficult, however, because additional considerations are rooted in fundamental differences in behavior and physiology of the insects, including activity during scotophase, threshold responses to UV, and susceptibility to subtle aspects of the trap design. Of all trapping methods, light traps are the most subject to variation in efficiency from insect to insect, from night to night, and from site to site because they rely on the disturbance of normal behavior for their functioning (Southwood, 1978).

The relationship between flight physiology and attraction to UV may be a productive line of inquiry when seeking to explain differential attraction of ladybird beetles to blacklight traps. Long distance, between-habitat flights not associated with dormancy ("hectic trivial flight" - Hodek et al., 1993) often occurs in coccinellids when large numbers of newly emerged adults coincide with declining aphid populations (Hagen, 1967). These flights are usually post-teneral and pre-reproductive, and thus roughly conform to the flight-oogenesis syndrome, where ovarian activity is inversely related to flight activity (Hodek, 1973; Rankin \& Rankin, 1980; Hodek et al., 1993). Hesler et al. (2004) noted that if this hectic trivial flight in coccinellids occurred at night, the probability of their encountering a blacklight trap might be increased. In addition to night flight, however, migrating insects exhibit physiological shifts that include altered responsiveness to phototactic stimuli (Southwood, 1978; Menzel, 1979; Prokopy, 1986; Dingle, 1996), particularly if those stimuli are associated with orientation and navigation (Baker \& Sadovy, 1978; Osorio \& Vorobyev, 2005). The sporadic appearance of non-Harmonia coccinellids at blacklight traps, then, may be attributed to shifts in ratios of migratory to non-migratory flyers throughout the year and throughout the life cycle (Rankin \& Rankin, 1980), and to whether the traps are located in migratory flight corridors. Several lines of evidence suggest this may be the case. Hesler et al. (2004), for example, caught a total of $430 \mathrm{H}$. convergens at a blacklight trap in South Dakota, but all were captured on a single night. In the current study, 18 of 19 female Myzia pullata captured in 2004 had undeveloped ovarioles. Conversely, the failure of the light traps to attract $C$. septempunctata, $H$. convergens and $C$. munda from a nearby aphid-infested field in this study may be related to the well-fed, reproductively active status of the beetles. Coccinella septempunctata is considered a day-active ladybird, with a circadian rhythm of sensitivity to light stimuli (Zotov, 2008). Nonetheless, Honěk \& Kocourek (1986) captured numerous C. septempunctata during their light trapping study, likely because the insects they captured were in long distance flight.

If the suggestion that (1) coccinellids are attracted to blacklight traps primarily during long distance flights is valid, and that (2) this attraction is rooted in physiological shifts that change sensory and/or mobility thresholds, then it is obvious that $H$. axyridis is the exception to the rule. The data reported here for alfalfa fields indicate that $H$. axyridis may exhibit more within-habitat flight at night than other coccinellids. This deserves further attention, particularly since $H$. axyridis escapes sticky cards more easily than does C. septempunctata or C. maculata (Stephens \& Losey, 2004) and thus may be under-represented in Table 2. Even in absence of a nearby point source of $\mathrm{UV}$, then, $H$. axyridis may exhibit more activity during scotophase than do other ladybird species. It is also possible that flight modes (and associated physiological shifts) are more nebulous in $H$. axyridis than in other coc- 
cinellids. There are sometimes vague boundaries between movement categories (Dingle, 1996), and arboreal ladybirds such as $H$. axyridis may conform only loosely to the flight-oogenesis syndrome, with a tendency for dispersal flights throughout their lives regardless of local conditions (Evans, 2003). In any case, the role of UV in the sensory ecology of $H$. axyridis is distinctive, relative to other coccinellids, and adds to the growing list of unique characteristics (Soares et al., 2008) that may contribute to its success in invading new environments.

ACKNOWLEDGEMENTS. I thank J. Bacheler, I. Hodek, S. Johnsen, G. Kennedy, D. Landis, and D. Stephan for productive discussions, A. Mullins for donation of the sticky traps, S. Bambara for help in the alfalfa fields, K. Ahlstrom (NCDA) for confirming the identification of all Coccinellidae, and C. Arellano for help with statistics. I am grateful to K. Snyder for permission to work in the alfalfa fields at North Carolina State University Lake Wheeler Road Field Laboratory.

\section{REFERENCES}

BAKER R.R. \& SAdovy Y. 1978: The distance and nature of the light trap response of moths. - Nature 276: 818-821.

ChAPIN J.B. \& BRou V.A. 1991: Harmonia axyridis (Pallas), the third species of the genus to be found in the United States (Coleoptera: Coccinellidae). - Proc. Entomol. Soc. Wash. 93: 630-635.

Dingle H. 1996: Migration. The Biology of Life on the Move. Oxford University Press, New York, 474 pp.

Evans E.W. 2003: Searching and reproductive behavior of female aphidophagous ladybirds (Coleoptera: Coccinellidae): a review. - Eur. J. Entomol. 100: 1-10.

Galvan T.L., Burkness E.C., Koch R.L. \& Hutchison W.D. 2009: Multicolored lady beetle (Coleoptera: Coccinellidae) activity and wine grape phenology: Implications for pest management. — Environ. Entomol. 38: 1563-1574.

Gerson E.A. \& Kelsey R.G. 1997: Attraction and direct mortality of pandora moths, Coloradia pandora (Lepidoptera: Saturniidae), by nocturnal fire. - Forest Ecol. Manag. 98: $71-75$.

HaGEN K.S. 1967: Biology and ecology of predaceous Coccinellidae. - Annu. Rev. Entomol. 12: 79-104.

HesLer L.S., Kieckhefer R.W. \& CATANGUi M.A. 2004: Surveys and field observations of Harmonia axyridis and other Coccinellidae (Coleoptera) in Eastern and Central South Dakota. Trans. Am. Entomol. Soc. 130: 113-133.

Hoder I. 1973: Biology of Coccinellidae. Dr. W. Junk, The Hague, $260 \mathrm{pp}$.

Hodek I. \& HonĚK A. 1996: Ecology of Coccinellidae. Kluwer Academic Publishers, Dordrecht, 464 pp.

Hodek I., Iperti G. \& Hodková M. 1993: Long distance flights in Coccinellidae (Coleoptera). - Eur. J. Entomol. 90: 403-414.

HoněK A., Martinková Z. \& PeKÁr S. 2005: Temporal stability of morph frequency in central European populations of Adalia bipunctata and $A$. decempunctata (Coleoptera: Coccinellidae). - Eur. J. Entomol. 102: 437-442.

HonĚK A. \& KoCOUReK F. 1986: The flight of aphid predators to a light trap: possible interpretations. In Hodek I. (ed.):
Ecology of Aphidophaga. Dr. W. Junk, Dordrecht, pp. 333-338.

Kenis M., Roy H.E., Zindel R. \& Majerus M.E.N. 2008: Current and potential management strategies against Harmonia axyridis. - BioControl 53: 235-252.

Koch R.L. \& Hutchinson W.D. 2003: Phenology and blacklight trapping of the multicolored Asian lady beetle (Coleoptera: Coccinellidae) in a Minnesota agricultural landscape. $-J$. Entomol. Sci. 38: 477-480.

MA G. \& MA C.-S. 2012: Differences in the nocturnal flight activity of insect pests and beneficial predatory insects recorded by light traps: Possible use of a beneficial-friendly trapping strategy for controlling insect pests. - Eur. J. Entomol. 109: 395-401.

Menzel R. 1979: Spectral sensitivity and colour vision in invertebrates. In Autrum H. (ed.): Handbook of Sensory Physiology. Vol. VII/6A. Springer, Berlin, pp. 503-580.

Nabli H., Bailey W.C. \& Necibi S. 1999: Beneficial insect attraction to light traps with different wavelengths. - Biol. Contr. 16: 185-188.

Nalepa C.A. 2007: Harmonia axyridis (Coleoptera: Coccinellidae) in buildings: Relationship between body height and crevice size allowing entry. - J. Econ. Entomol. 100: 1633-1636.

Nalepa C.A., Kennedy G.G. \& Brownie C. 2005: Role of visual contrast in the alighting behavior of Harmonia axyridis (Coleoptera: Coccinellidae) at overwintering sites. - Environ. Entomol. 34: 424-431.

Osorio D. \& Vorobyev M. 2005: Photoreceptor spectral sensitivities in terrestrial animals: adaptations for luminance and colour vision. - Proc. R. Soc. (B) 272: 1745-1752.

PRoKopy R.J. 1986: Visual and olfactory stimulus interaction in resource finding by insects. In Payne T.L., Birch M.C. \& Kennedy C.E.J. (eds): Mechanisms in Insect Olfaction. Clarendon Press, Oxford, pp. 81-89.

RANKIN M.A. \& RANKIN S. 1980: Some factors affecting presumed migratory flight activity of the convergent lady beetle Hippodamia convergens (Coccinellidae: Coleoptera). - Biol. Bull. 158: 356-369.

Soares A.O., Borges A., Borges P.A.V., Labrie G. \& Lucas E. 2008: Harmonia axyridis: What will stop the invader? - BioControl 53: 127-145.

Southwood T.R.E. 1978: Ecological Methods with Particular Reference to the Study of Insect Populations. 2nd ed. Chapman and Hall, London, 524 pp.

Stanković V.M., Koren T. \& Stanković I. 2011: The Harlequin ladybird continues to invade southeastern Europe. - Biol. Invasions 13: 1711-1716.

Stephens E.J. \& Losey J.E. 2004: Comparison of sticky cards, visual and sweep sampling of coccinellid populations in alfalfa. - Environ. Entomol. 33: 535-539.

Waldvogel M.G., Bambara S.B., Baker J.R. \& OrR D.B. 2003: Multicolored Asian Lady Beetle inside Houses. NC Cooperative Extension Service, http://www.ces.ncsu.edu/depts/ent/ notes/Other/goodpest/note107.html, accessed 13 Feb 2013.

Zотоv V.A. 2008: Circadian rhythm of light sensitivity in beetles Coccinella septempunctata (Coleoptera, Coccinellidae): Effects of illumination and temperature. - Zool. Zh. 87: 1472-1475 [in Russian, English abstr.].

Received February 20, 2013; revised and accepted May 9, 2013 